\title{
PENGARUH AKTIVITAS, LIKUIDITAS DAN SOLVABILITAS TERHADAP PROFITABILITAS PADA PERUSAHAAN MAKANAN DAN MINUMAN DI BEI 2014-2018
}

\author{
Firdaus Fridikus Matondang ${ }^{1}$ \\ Eni Wuryani \\ 1,2 Universitas Negeri Surabaya, Surabaya, Jawatimur, Indonesia \\ email :firdausmatondang23@gmail.com
}

\begin{abstract}
ABSTRAK
Tujuan dari penelitian ini adalah untuk mengetahui pengaruh aktivitas, likuiditas dan solvabilitas terhadap profitabilitas pada perusahaan makanan dan minuman yang terdaftar di Bursa Efek Indonesia pada tahun 2014-2018. Sampel yang digunakan ialah 60 data laporan keuangan tahunan dipilih berdasarkan sampel yang ditargetkan menggunakan purposive sample. Jenis penelitian ini adalah penelitian kuantitatif. Teknis analisis data menggunakan regresi linear berganda menggunakan alat uji SPSS. Pengukuran variabel penelitian menggunakan rasio perputaran modal kerja, rasio cepat, rasio utang terhadap ekuitas dan rasio pengembalian aset. Hasil penelitian menunjukkan bahwa aktivitas dan likuiditas secara parsial mempengaruhi profitabilitas sedangkan solvabilitas tidak mempengaruhi profitabilitas.
\end{abstract}

Kata Kunci: Aktivita;Likuiditas;Profitabilitas;Solvabilitas

\begin{abstract}
The purpose of this study was to determine the effect of activity, liquidity and solvency on profitability in food and beverage companies listed on the Indonesia Stock Exchange in 20142018. The sample used is 60 annual financial report data selected based on a targeted sample using a purposive sample. This type of research is quantitative research. The data analysis technique used multiple linear regression with the help by means of SPSS test equipment. Measurement of research variables using working capital turnover ratio, quick ratio, debt to equity ratio and return on asset. The results showed that activity and liquidity partially affected profitability, while solvency did not affect profitability.
\end{abstract}

Keywords: Activity;:Liquidity;Profitability;Solvency 


\section{PENDAHULUAN}

Perusahaan sebagai badan usaha umumnya memiliki tujuan yang ingin dicapai. Salah satunya adalah untuk mewujudkan kepentingan anggotanya. Tujuan lain dari pembentukan perusahaan adalah untuk menghasilkan laba. Tercapainya suatu tujuan tergantung bagaimana manajer dalam mengendalikan perusahaan. Pengambilan keputusan internal dan eksternal perusahaan dapat dilihat dari baik tidaknya kinerja perusahaan. Menurut Rofiah dkk, (2017) untuk dapat terus beroperasi, kinerja perusahaan harus terus meningkat. Kinerja yang menururun akan menyebabkan perusahaan sulit untuk mendapatkan pinjaman dari pihak investor. Pihak-pihak yang berkepentingan khususnya manajer akan berusaha untuk meningkatkan profit demi masa depan perusahaan. Kinerja keuangan perusahaan yang meningkat merupakan salah satu cara menjaga kualitas kerja dalam perusahaan.

Tabel 1.

Persentase Rasio Keuangan Pada Varibel Penelitian Tahun 2016-2018

\begin{tabular}{|c|c|c|c|c|c|}
\hline Nama Perusahaan & Tahun & $\begin{array}{c}\text { Perputaran } \\
\text { Modal } \\
\text { Kerja } \\
(\%) \\
\end{array}$ & $\begin{array}{c}\text { Rasio } \\
\text { Cepat } \\
(\%)\end{array}$ & $\begin{array}{c}\text { Rasio Utang } \\
\text { terhadap } \\
\text { Ekuitas } \\
(\%) \\
\end{array}$ & $\begin{array}{c}\text { Rasio } \\
\text { Pengembalian } \\
\text { Aset } \\
(\%) \\
\end{array}$ \\
\hline \multirow{3}{*}{ PT Tiga Pilar Sejahtera Food } & 2016 & 1,90 & 0,78 & 1,17 & 7,77 \\
\hline & 2017 & $-0,60$ & 0,19 & $-1,59$ & $-9,71$ \\
\hline & 2018 & $-0,36$ & 0,14 & $-1,53$ & $-6,80$ \\
\hline \multirow[t]{3}{*}{ PT Wilmar Cahaya Indonesia } & 2016 & 6,83 & 1,09 & 0,61 & 6,10 \\
\hline & 2017 & 7,83 & 1,29 & 0,54 & 6,00 \\
\hline & 2018 & 5,58 & 3,01 & 0,20 & 5,40 \\
\hline \multirow[t]{3}{*}{ PT Delta Djakarta } & 2016 & 0,85 & 6,27 & 0,18 & 21,18 \\
\hline & 2017 & 0,73 & 7,36 & 0,17 & 20,86 \\
\hline & 2018 & 0,75 & 6,13 & 0,19 & 22,19 \\
\hline \multirow[t]{3}{*}{ PT Indofood CBP } & 2016 & 3,78 & 0,12 & 0,56 & 13,1 \\
\hline & 2017 & 3,65 & 1,95 & 0,56 & 11,7 \\
\hline & 2018 & 5,58 & 1,39 & 0,51 & 14,1 \\
\hline \multirow[t]{3}{*}{ PT Multi Bintang Indonesia } & 2016 & $-7,68$ & 0,43 & 1,77 & 0,47 \\
\hline & 2017 & $-14,92$ & 0,40 & 1,36 & 0,53 \\
\hline & 2018 & $-10,43$ & 0,54 & 1,47 & 0,42 \\
\hline \multirow[t]{3}{*}{ PT Mayora Indonesia } & 2016 & 3,78 & 2,80 & 1,06 & 11 \\
\hline & 2017 & 3,36 & 1,98 & 1,03 & 11 \\
\hline & 2018 & 3,05 & 1,95 & 1,06 & 10 \\
\hline \multirow[t]{3}{*}{ PT Nippo Indosari Corporindo } & 2016 & 4,01 & 0,60 & 1,02 & 9,58 \\
\hline & 2017 & 1,93 & 2,21 & 0,62 & 2,97 \\
\hline & 2018 & 2,05 & 3,45 & 0,51 & 2,89 \\
\hline \multirow[t]{3}{*}{ PT Sekar Bumi } & 2016 & 0,03 & 0,78 & 1,72 & 2,11 \\
\hline & 2017 & 0,41 & 1,06 & 0,59 & 1,59 \\
\hline & 2018 & 0,01 & 0,89 & 0,70 & 0,90 \\
\hline \multirow[t]{3}{*}{ PT Sekar Laut } & 2016 & 15,62 & 0,60 & 0,92 & 3,60 \\
\hline & 2017 & 0,01 & 0,69 & 1,07 & 3,60 \\
\hline & 2018 & 0,49 & 0,69 & 1,20 & 4,30 \\
\hline \multirow[t]{3}{*}{ PT Siantar Top } & 2016 & 7,24 & 1,15 & 1,00 & 7,45 \\
\hline & 2017 & 4,86 & 1,79 & 0,69 & 9,22 \\
\hline & 2018 & 4,9 & 1,39 & 0,60 & 9,63 \\
\hline
\end{tabular}

Sumber: diolah oleh penulis,2020 
Menurut Hermuningsih, (2013) untuk mengetahui prospek yang baik mengenai perusahaan dimasa depan dapat dilihat dari perolehan profitabilitas perusahaan. Kelangsungan hidup suatu badan usaha akan terjaga jika tingkat profitabilitas perusahaan tinggi. Untuk menilai profitabilitas perusahaan dapat dilakukan dengan berbagai macam tergantung pada laba dan aktiva yang akan dibandingkan satu dengan yang lain. Oleh karena itu tidak mengherankan apabila perusahaan dalam melakukan penghitungan profitabilitas melakukan cara yang berbeda-beda. Yang penting profitabilitas apa yang digunakan sebagai alat pengukuran tingkat efektivitas perusahaan. Salah satu faktor yang berkontribusi terhadap kenaikan profitabilitas adalah aktivitas, solvabilitas dan likuiditas.

Berdasarkan Tabel 1. dapat dilihat pertumbuhan rasio pengembalian aset pada periode 2016 sampai dengan 2018 pada beberapa perusahaan sub sektor makanan dan minuman mengalami fluktuasi. Fenomena yang diperoleh pada penelitian ini berhubungan dengan seberapa mampu perusahaan mengontrol penggunaan kas, piutang dan persediaan yang dimiliki untuk memperoleh profitabilitas yang maksimal. Aktivitas yang diproksi rasio perputaran modal kerja pada perusahaan PT Tiga Pilar Sejahtera Food pada periode 2016 sebesar 1,90\%, tahun 2017 0,60\% dan 2018 sebesar 0,36\% mengalami penurunan dari tahun ke tahun. Penurunan rasio perputaran modal kerja ini diikuti dengan turunnya perolehan rasio pengembalian aset. Rasio pengembalian aset pada perusahaan PT Tiga Pilar Sejahtera Food pada tahun 2016 sebesar 7,77\%, tahun $2017-9,71 \%$ dan tahun 2018 sebesar $-6,80 \%$. Rasio likuiditas yang diproksi rasio cepat menunjukkan pada tahun 2016 sampai 2018 mengalami penurunan.

Likuiditas yang diproksi dengan rasio cepat pada perusahaan PT Tiga Pilar Sejahtera Food mengalami penurunan dari tahun 2016 sampai 2018. Pada tahun 2016 rasio cepat sebesar $0,78 \%$, tahun 2017 sebesar 0,19 dan tahun 2018 sebesar 0,14 , penurunan ini sejalan dengan menurunnya rasio pengembalian aset yang diperoleh prusahaan dari tahun 2016 sampai 2018. Solvabilitas yang diproksi PT Tiga Pilar Sejahtera Food juga mengalami penurunan dari tahun 2016 sampai 2018. tahun 2016 memperoleh sebesar 1,17\% , tahun $2017-1,59 \%$ dan tahun 2018 sebesar $-1,53 \%$. hal ini diikuti dengan menurunnya persentasi rasio pengembalian aset yang diperoleh perusahaan.

Rasio perputaran modal kerja perusahaan PT Delta Djakarta mengalami fluktuasi dimana tahun 2016 perusahaan memperoleh rasio cepat sebesar $0,85 \%$, tahun 2017 mengalami penurunan menjadi 0,73\% tetapi pada tahun 2018 naik kembali menjadi $0,75 \%$ hal ini sejalan dengan perolehan rasio pengembalian aset dimana pada tahun 2016 memperoleh 21,18\%, tahun 2017 turun menjadi 20,86\% dan pada tahun 2018 mengalami kenaikan menjadi 22,19\%.

Rasio cepat yang diperoleh perusahaan PT Delta Djakarta tahun 2017 mengalami peningkatan dibandingkan tahun 2016, tetapi pada tahun 2017 terjadi penurunan kembali. Rasio utang pada ekuitas pada perusahaan PT Delta Djakarta pada tahun 2017 mengalami penurunan menjadi 0,17\%, sedangkan tahun 2018 mengalami kenaikan menjadi $22,19 \%$, untuk rasio pengembalian aset pada tahun 2017 mengalami penurunan dan tahun 2018 mengalami peningkatan. Begitu juga dengan perusahaan lain yang dijadikan sample penelitian. 
Perusahaan PT Siantar Top pada tahun 2016 sampai tahun 2018 perputaran modal kerja mengalami fluktuasi dimana tahun 2017 turun menjadi 4,86\% tetapi pada tahun 2018 naik kembali menjadi 4,9\% namu kenaikan hanya selisih $0.04 \%$. tetapi tingkat perolehan rasio pengembalian aset dari tahun ke tahun mengalami peningkatan dimana tahun 2016 sebesar 7,45\% , tahun $20179,22 \%$ dan tahun 2018 menjadi $9,63 \%$.

Rasio cepat pada perusahaan PT Siantar Top juga mengalami fluktuasi dimana tahun 2016 memperoleh persentasi rasio cepat sebesar $1,15 \%$ dan mengalami peningkatan 2017 sebesar 1,79. Tetapi pada tahun 2017 mengalami penurunan menjadi 1,39 namun hal ini berbanding terbalik dengan rasio pengembalian aset dimana tiap tahunnya perusahaan memperoleh rasio pengembalian aset dari tahun ke tahun mengalami peningkatan.

Rasio utang terhadap ekuitas pada perusahaan PT Siantar Top dari tahun ketahun mengami penurunan tetapi perolehan rasio pengembalian aset mengalami peningkatan dari tahun 2016 sampai tahun 2018.

Persentase perolehan rasio perputaran modal kerja, rasio cepat dan rasio utang pada ekuitas terhadap peningkatan rasio pengembalian aset setiap perusahaan perlu untuk diperhatikan oleh manajer perusahaan. Terjadinya fluktuasi pada rasio keuangan dari tahun ke tahun juga menjadi salah satu alasan dilakukan dilakukan penelitian ini. Pemilihan subsektor makanan dan minuman pada penelitian ini karena pada sektor ini menyediakan kebutuhan pokok bagi masyarakat. Perkembangan sektor makanan dan minuman akan meningkatkan peluang investasi.

Penelitian terdahulu menguji pengaruh aktivitas, solvabilitas dan likuiditas terhadap profitabilitas. Hasil penelitian yang dilakukan Meita dan Silvia (2018) membuktikan rasio likuiditas yang diproksi rasio lancar, solvabilitas diproksi rasio utang dan aktivitas yang diproksi rasio perputaran aktiva berpengaruh pada profitabilitas. Penelitian lain dilakukan oleh (Rofiah dkk., 2017) menunjukkan bahwa Efisiensi Modal Kerja, Likuiditas dan Solvabilitas terhadap Profitabilitas pada Perusahaan Food dan Beverage yang terdaftar di Bursa Efek Indonesia (BEI). Namun berbeda dengan hasil penelitian yang dilakukan Nugroho (2012) Efisiensi modal kerja, likuiditas dan solvabilitas tidak mempengaruhi profitabilitas.

Berdasarkan latar belakang dan hasil penelitian terdahulu yang tidak konsisten, maka penelitian ini akan melakukan pengujian mengenai pengaruh aktivitas, likuiditas dan solvabilitas terhadap profitabilitas pada perusahaan sub sektor makanan dan minuman yang sudah terdaftar di BEI tahun 2014-2018. Rumusan masalah penelitian ini yaitu: apakah aktivitas berpengaruh pada profitabilitas, apakah likuiditas berpengaruh pada profitabilitas dan apakah solvabilitas mempengaruhi profitabilitas. Harapannya kegunaan teoritis yang diperoleh pada penelitiaan ini dapat berkontribusi untuk kemajuan ilmu akuntansi.

Dasar teori yang melandasi penelitian ini ada dua : Signaling theory dan Pecking order theory. Menurut Gumandi (2018) Signaling theory merupakan informasi mengenai laporan keuangan dimana profitabilitas dianggap sebagai sinyal dari perkiraan pendapatan yang diperoleh manajemen. Informasi dalam laporan keuangan merupakan sinyal perusahaan kepada kreditur mengenai kinerja 
perusahaan. Penilaian terhadap baik tidaknya kinerja perusahaan dapat dilihat dari seberapa besar sinyal yang diberikan manajer kepada investor mengenai kondisi perusahaan (Setiawanta dkk., 2019). Kemampuan yang terus meningkat yang tercermin dalam rasio keuangan akan membuat inventor tertarik untuk menginvestasikan uangnya kepada perusahaan.

Perusahaan dengan kualiatas yang lebih bagus diharapkan agar lebih berani mengunakan sinyal-sinyal tertentu yang menunjukkan bahwa perusahaan mereka lebih baik dan tidak dapat dibandingkan dengan perusahaan yang lain. Signaling theory menjelaskan bahwa dorongan memberikan informasi tentang perusahaan adalah adanya perbedaan informasi diantara pihak luar dan manajer bisnis dikarenakan manajer bisnis lebih mengetahui informasi lebih banyak tentang keadaaan perusahaan (Yudhatama dan Wibowo, 2014).

Menurut Jumono dkk., (2013) Pecking order theory menunjukkan perusahaan dalam memilih pendanaan untuk menjalankan operasional sehari-hari cenderung memilih berdasarkan urutan resiko. Perusahaan cenderung menganalisis besarnya biaya yang akan dikeluarkan untuk membiayaan operasional perusahaan. Oleh karena itu pemilihan sumber dana yang akan dipergunakan perlu untuk tetapkan. Pembiayaan internal lebih diutamakan dari pembiayaan eksternal. Perusahaan yang ingin tumbuh pada dasarnya selalu membutuhkan modal yang salah satunya bersumber dari pinjaman. Tetapi bagi perusahaan tidak sesederhana itu untuk mendapatkan pinjaman karena pihak kreditur biasanya terlebih dahulu menganalisis kondisi perusahaan, apakah perusahaan dibenarkan untuk diberikan hutang. Pecking order theory menjelaskan alasan perusahaan yang memperoleh laba yang tinggi memiliki lebih sedikit utang dan perusahaan dengan laba rendah cenderung memiliki utang yang tinggi. Hal ini dikarenakan sumber pendanaan yang berasal dari perusahaan tidak cukup untuk memenuhi pembiayaan untuk aktivitas perusahaan dan pendanaan yang lebih disukai adalah utang.

Kekurangan pembiayaan internal perusahaan memperlihatkan kondisi dimana kas yang dimiliki perusahaan dari kegiatan operasi perusahaan tidak mampu untuk membayar kegiatan investasi dan operasional dimasa depan. Pecking order theory juga menjelaskan mengapa ada asimetri informasi tentang penggunaan sumber pendanaan yang berasal dari luar antara manajemen perusahaan dengan pihak kreditur. Perbedaan asimetri terjadi karena lebih banyak informasi diketahui para manajer perusahaan tentang keadaan perusahaan saat ini dan propek masa depan yang dihadapi.

Laporan keuangan dibuat dengan maksud menginformasikan kemajuan kinerja perusahaan baik mengenai posisi keuangan maupun perubahan yang terjadi bagi sebagian pihak yang berkaitan dalam pengambilan keputusan (Kasmir, 2016:7). Selain itu, berbagai informasi yang sudah disediakan mengenai kondisi posisi perusahaan mempunyai maksud dan tujuan yaitu untuk melakukan penilaian terhadap kinerja manajemen. Kinerja perusahaan dinilai melalui laporan keuangan laba rugi dan neraca. Agar lebih memahami laporan keuangan oleh setiap orang, diperlukan analisis laporan keuangan. Bagi manajer dan pemilik perusahaan analisis bertujuan untuk memperoleh kondisi posisi keuangan perusahaan Kasmir (2010:90). 
Menurut (Kasmir, 2016:69) dua metode digunakan untuk menganalisis laporan keuangan yaitu analisis vertikal dan analisis horizontal. Analisis vertical yaitu analisis yang digunakan hanya dalam satu periode pelaporan keuangan. Langkah-langka analisis dilakukan antar komponen yang ada dalam satu periode dan informasi yang didapat hanya satu periode dan tidak ada kemajuan dari satu periode keperiode berikutnya. Analisis horizontal yaitu analisis dengan membandingkan laporan keuangan selama beberapa periode. Hasil analisis menunjukkan kemajuan perusahaan tiap tahunnya.

Laba merupakan suatu hal yang sangat penting bagi perusahaan karena untuk melangsungkan hidupnya suatu perusahaan haruslah berada dalam keadaan yang menguntungkan, tanpa keuntungan akan sulit bagi perusahaan untuk menarik modal dari luar (Rofiah dkk., 2017). Para direktur, pemilik perusahaan dan yang paling utama pihak manajemen perusahaan akan berusaha meningkatkan keuntungan ini, karena disadari betul pentingnya arti keuntungan bagi masa depan perusahaan. Salah satu yang bisa dilakukan perusahaan adalah menjaga kualitas kerja dalam perusahaan itu sendiri, terutama dalam upaya hal peningkatan kinerja keuangan perusahaan. Perusahaan dalam mencapai tujuannya harus selalu memperhatikan perkembangan di setiap periodenya sehingga bisa terlihat kemajuan dari kinerja perusahaan tersebut.

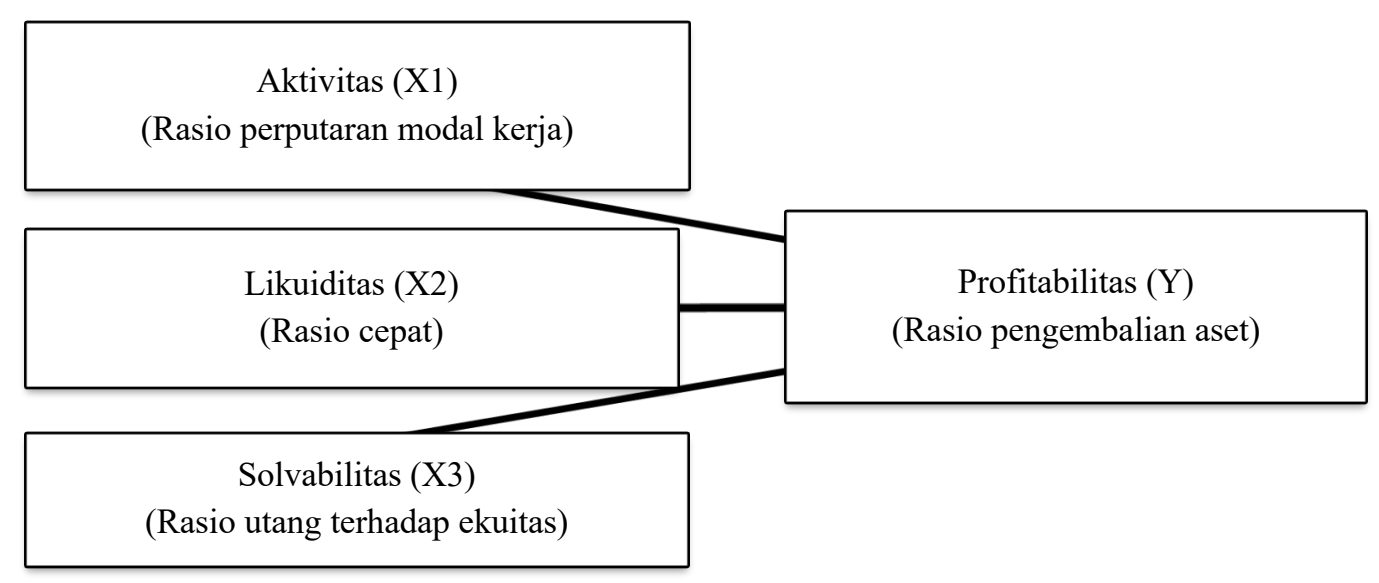

Gambar 1. Kerangka Konsep Penelitian

Sumber: diolah oleh penulis, 2020

Menurut Kasmir (2010:115) profitabilitas ialah hasil yang diperoleh dengan angka persentasi dengan membandingkan antara laba dan aktiva yang dimiliki perusahaan. Indikator yang dipergunakan utuk mengukur tingkat efesiensi perusahaan menghasilkan profit yang berkaitan dengan penjualan, modal sendiri dan total aktiva yang dimiliki dapat menggunakan rasio profitabilitas. Profitabilitas juga dipergunakan untuk mengetahui tingkat efiktivitas manajemen pada pengelolaan perusahaan. Semakin tinggi profitabilitas menunjukkan kinerja manajer untuk mengelolah perusahaan semakin baik, karena untuk menghasilkan profit yang tinggi dibutuhkan aktivitas produksi yang berkualiatas dan manajemen yang baik (Safitri dkk., 2013). 
Perbandingan berbagai komponen yang terdapat pada laporan keuangan yang diperoleh dari neraca dan laporan laba rugi dapat dapat digunakan untuk memperoleh hasil pengukuran profitabilitas. Untuk memantau dan melakukan evaluasi peningkatan profitabilitas dapat diperoleh dari hasil pengukuran beberapa periode pelaporan keuangan tahunan yang telah dibuat sebelumnya (Intan, 2020). Dengan menganalisis rasio keuangan secara teratur manajer dapat menentukan opsi efisisensi untuk peningkatan profitabilitas. Langkah lainnya adalah dengan melakukan perbandingan rasio rata-rata pendapatan perusahaan.

Rasio aktivitas digunakan untuk mengetahui tingkat efektivitas bisnis ketika menggunakan aset atau sumber daya yang dimiliki (Kasmir, 2016:114). Hasil pengukuran dapat juga dijadikan sebagai acuan untuk mengetahui tingkat efesisensi perusahaan menggunakan sumber dana yang dimiliki perusahaan dan seberapa baik manajer dalam mengelola aset untuk menjalankan operasional perusahaan. Untuk menghitung rasio aktivitas dapat digunakan dengan cara penghitungan rasio: perputaran piutang, perputaran aset, perputaran aktiva, perputaran modal kerja, perputaran aktiva tetap.

Menurut Mashady dkk. (2014) rasio aktivitas diproksikan dengan rasio perputaran modal kerja digunakan untuk menilai keefisienan penggunaan aset pada periode tertentu. Semakin tinggi tingkat perputaran modal kerja, semakin besar aliran kas yang diterima perusahaan, artinya dalam mengelolah aktivitas operasional perusahaan semakin baik (Iskandar dkk., 2014). Hasil pengukuran rasio ini dapat dijadikan sebagai pengambil keputusan, perusahaan telah efisien dan efektif atau tidak memanfaatkan sumber dana menjalankan operasional perusahaan. Efesiensi yang dilakukan misalnya bidang penjualan (Putri, 2018).

Sesuai dengan Signaling theory dan Pecking order theory kenaikan perputaran modal yang semakin meningkat dapat menjadi sinyal bagi pihak kreditur bahwa perusahaan dapat menjalankan kegiatan operasional dengan baik dan perputaran modal yang tinggi menunjukkan dana yang dimiliki perusahaan dapat digunakan untuk meningkatkan penjualan bersih sehingga perusahaan tidak perlu melakukan pinjaman yang akan memperkecil kesempatan memperoleh laba. Hal ini didukung dengan penelitian yang dilakukan oleh Setyoningsih, (2014), Utami dan Prasetiono, (2016) dimana aktivitas memiliki pengaruh pada profitabilitas. Hipotesis $\left(\mathrm{H}_{1}\right)$ yang diperoleh :

$\mathrm{H}_{1}$ : Aktivitas mempengaruhi profitabilitas

Menurut Kasmir (2010:110) lidikuitas yaitu indikator yang memperihatkan tingkat kesanggupan perusahaan untuk melunasi kewajiban yang sudah pada waktunya untuk dibayar. Ketika ditagih, utang yang sudah waktunya untuk dibayar perusahaan harus mampu melunasi kewajiban tersebut. Jumlah aset yang tersedia untuk melunasi dapat digunakan untuk mengukur tingkat keamanan pada perusahaan. Menurut Kasmir (2016:132) tujuan penggunaan likuiditas pada perusahaan adalah: pertama, mengetahui seberapa baik perusahaan untuk melunasi utang jangka pendek pada saat akan ditagih, artinya kemampuan untuk membayar harus sesuai dengan tenggang waktu yang sudah disepakati. Kedua, untuk mengetahui banyaknya uang tunai yang disediakan untuk melunasi hutang. Ketiga, untuk memberitahu posisi keuangan dari periode-keperiode berikutnya. Keempat, untuk memperoleh informasi mengenai kekurangan perusahaan dari 
masing-masing komponen aset lancar dan utang lancar. Kelima, sebagai acuan bagi manajer meningkatkan kinerja. Rasio ini terdapat beberapa jenis antara lain rasio cepat, inventory net working capital, rasio kas, rasio perputaran kas dan rasio lancar.

Likuiditas yang yang dianalisis menggunakan rasio cepat dipergunakan untuk menentukan sejauh mana perusahaan mampu melunasi utang jangka pendeknya dengan aset lancar yang dimiliki. Manajemen likuiditas yang buruk berdampak pada aktivitas operasi perusahaan. Mengabaikan kondisi likuiditas dapat mengurangi tingkat kepercayaan pihak luar pada perusahaan. Tingginya aktiva lancar mengindikasikan dana yang dikeluarkan untuk membayar utang lancar tidak terlalu besar. Hal ini menunjukkan kinerja perusahaan dalam memperoleh laba semakin baik (Marzuki, 2019). Sesuai dengan Signaling theory dan Pecking order theory bahwa signal baik bagi investor terhadap kinerja perusahaan dapat dilihat dari seberapa baik perusahaan menggunakan hutang untuk menjalankan operasional perusahaan. Proporsi hutang yang sedikit menunjukkan pendanaan yang yang lebih banyak digunakan berasal dari dana milik perusahaan itu sediri. Hal ini didukung dengan penelitian yang dilakukan oleh Alexandre dan Wiksuana (2018) dan penelitian yang dilakukan Yusra (2016) likuiditas mempunyai pengaruh terhadap profitabilitas yang diproksi dengan rasio pengembailan ekuitas. Hipotesis $\left(\mathrm{H}_{2}\right)$ diperoleh :

$\mathrm{H}_{2}$ : Likuiditas mempengaruhi profitabilitas

Menurut Wibowo (2013) solvabilitas dipergunakan untuk mengetahui seberapa besar potensi perusahaan untuk membayar semua kewajibannya menggunakan seluruh aset yang dimiliki jika perusahaan dilikuidasi. Untuk dapat beroperasi, setiap perusahaan memiliki kebutuhan pendanaan yang berbeda. Oleh karena itu dibutuhkan dana yang dapat menyokong perusahaan agar dapat berfungsi dengan baik (Dwi dan Febrianto, 2015). Ini berarti bahwa sejumlah uang harus selalu tersedia sehingga ketika dibutuhkan dapat dipergunakan. Rasio solvabilitas terdapat terdapat beberapa jenis antara lain : rasio utang terhadap ekuitas, rasio utang jangka panjang terhadap ekuitas dan rasio utang pada aset.

Menurut Kholifah dan Dyah A (2016) solvabilitas yang diproksi rasio utang terhadap ekuitas dipergunakan untuk menentukan seberapa banyak aset yang dibiayai oleh utang. Tingkat perolehan rasio utang terhadap ekuitas yang meningkat dan jumlah aset tidak ada perubahan, maka utang yang dimiliki akan semakin bertambah. Dampaknya profitabilitas yang dihasilkan perusahaan akan berkurang dan ini dapat dianggap investor menjadi sinyal bahwa perusahan sedang dalam keadaan tidak baik, sehingga membuat pihak investor enggan untuk berinvetasi pada perusahaan.

Menurut Fadhilah (2016) kesanggupan perusahaan untuk memperoleh tambahan pinjaman dari investor akan menurun apabila besaran rasio utang lebih besar dari aset perusahaan. Signaling theory dan Pecking order theory menjelaskan dana yang bersumber lebih besar dari utang akan mempengaruhi kinerja perusahaan dan jumlah utang yang lebih besar akan menimbulkan resiko yang tinggi yang dapat menjadi sinyal buruk mengenai kinerja perusahaan yang dipandang pihak luar sebagai hal yang tidak baik. Hal ini didukung penelitian yang diperoleh Fadhilah (2016) dan Dwiputri dkk. (2019) yang membuktikan 
secara parsial solvabilitas berpengaruh signifikan dengan profitabilitas. Hipotesis $\left(\mathrm{H}_{3}\right)$ yang diperoleh:

$\mathrm{H}_{3}$ :Solvabilitas mempengaruhi profitabilitas.

\section{METODE PENELITIAN}

Dalam suatu penelitian wajib memakai tipe penelitian yang benar agar peneliti bisa mendapatkan deskripsi yang jelas terkait masalah yang dihadapi ketika melakukan suatu penelitian dan bagaimana cara mengatasi masalah tersebut. Jenis penelitian ini memakai penelitian kuantitatif yaitu memakai data sekunder annual report yang bisa diperoleh dari website resmi BEI (www.idx.co.id). Penelitian kuantitatif merupakan suatu tipe riset yang memakai pendekatan deduktif-induktif, yaitu diawali dari kerangka teori, pendapat parah ahli yang setelah itu diperluas menjadi suatu masalah yang harus dicari cara memecahkan masalah tersebut untuk dievaluasi dan dinilai.

Menurut Riduwan dan Akdon (2013:237) populasi ialah total keseluruhan objek penelitian yang dijadikan sebagai bahan penelitian yang terbentuk dari objek kuantitas yang diteliti. Seluruh perusahaan sub sektor makanan dan minuman yang terdaftar di BEI tahun 2014-2018 menjadi populasi yang dipilih untuk bahan penelitian.

Menurut Riduwan dan Akdon (2013:239), sample merupakan bagian kecil yang mewakili keseluruhan populasi. Sample juga diartikan sebagai bagian kecil dari kriteria yang telah ditetapkan yang mewakili keseluruhan populasi (Sugiyono, 2016:81). Pengambilan sample menggunakan purposive sampling. Purposive sampling merupakan pemilihan sample menggunakan kriteria yang sudah dipilih oleh peneliti, sehingga yang tidak termasuk dalam kriteria akan dikeluarkan dari sampel.

Menggunakan teknik purposive sampling diperoleh sample 60 data yang sesuai dengan kriteria pengambilan sampel yang dibuat peneliti. Hasil ini diperoleh dari 12 sample data laporan keuangan perusaaan dikalikan 5 tahun periode penelitian (2014-2018).

Tabel 2.

Pengambilan sample

\begin{tabular}{clc}
\hline Nomor & \multicolumn{1}{c}{ Keterangan } & Jumlah \\
\hline 1. & Perusahaan yang telah terdaftar di BEI periode 2014-2018 & 26 \\
2. & Aktif Listing periode 2014-2018 & $(12)$ \\
3. & Tidak mempublikasikan laporan keuangan periode 2014-2018 & $(2)$ \\
& Jumlah sample & 12 \\
& & $\mathbf{6 0}$ \\
\hline
\end{tabular}

Sumber: diolah oleh penulis,2020

Variabel yang mana keberadaannya dipengaruhi oleh variabel independen merupakan pengertian dari variabel dependen. Profitabilitas dijadikan sebagai variabel terikat dimana profitabilitas diproksikan dengan rasio pengembalian aset. 
Sedangkan varibel yang mana posisinya mempengaruhi posisi variabel dependen disebut dengan variabes bebas (independen).

Menurut Riana dan Ari (2016) rasio pengembalian aset menunjukkan seberapa tinggi keuntungan yang diperoleh perusahaan apabila dihitung menggunakan total aset. Menurut Harmono, (2014:110) rumus mengukur rasio ini adalah:

Retun on Assets $=\frac{\text { Laba Setelah Pajak }}{\text { Total Aset }} \times 100$

Untuk mengetahui seberapa besar efektivitas perusahaan menggunakan sumber daya yang ada dalam kurun waktu tertentu dapat menggunakan aktivitas yang diproksikan dengan rasio perputaran modal kerja (Kasmir, 2010:114). Untuk menghitung rasio ini menurut Kasmir, (2010:120) yaitu:

Working Capital Turnover $=\frac{\text { Penjualan Bersih }}{\text { Modal Kerja }} x 100$

Untuk mengetahui seberapa tinggi tingkat efektivitas perusahaan mampu untuk memenuhi liabilitas jangka pendek mempergunakan aktiva tanpa mengestimasi nilai persediaan dapat menggunakan rasio cepat (Kasmir, 2010:111). Untuk menghitung rasio ini menggunakan cara:

Quick Ratio $=\frac{\text { Aktiva Lancar }- \text { Persediaan }}{\text { Utang Lancar }} \times 100 \%$

Profitabilitas yang diproksikan rasio utang terhadap ekuitas dipergunakan untuk perbandingan total hutang terhadap ekuitas dan untuk menganalisis laporan keuangan yang menunjukkan jumlah jaminan yang tersedia bagi investor (Sugiyono, 2016:137). Untuk menghitung rasio ini sebeagai berikut:

Debt to Equity Ratio $=\frac{\text { Total Utang }}{\text { Total Modal }} \times 100 \%$

Menurut Sugiyono (2016:137) teknik pengumpulan data merupakan cara untuk mendapatkan informasi penelian. Informasi yang dimaksud adalah salah satu unsur penting yang dijadikan bahan penelitian. Selain itu teknik analis data juga dipergunakan untuk menganalisis informasi yang diperoleh guna mendapatkan hasil dan kesimpulan. Teknik analisis data pada penelitian mempergunakan bantuan alat uji aplikasi SPSS untuk menganalisis data deskriptif, uji asumsi klasik meliputi uji multikolinearitas, normalitas dan heteroskedastisitas. Selanjutnya menggunakan uji autokorelasi, regresi linear berganda dan uji hipotesis yang terdiri atas uji parsial, simultan dan koefisien determinasi.

Langkah-langkah menganalisis laporan keuangan dilakukan dengan cara mengumpulkan data mengenai akun-akun yang dibutuhkan pada peneltiian. 
Kedua, menghitung rasio keuangan, yaitu aktivitas yang diproksikan dengan rasio perputaran modal kerja, likuiditas yang diproksikan rasio cepat, solvabilitas yang diproksikan dengan ekuitas pada utang dan profitabilitas yang diproksikan dengan rasio pengembalian aset. Ketiga, mengelolah data yang sudah dianalisis dengan bantuan alat SPSS sesuai dengan alat uji yang dipergunakan. Keempat, menganalisis dan menarik kesimpulan.

\section{HASIL DAN PEMBAHASAN}

Analisis statistik deskriptif ialah hasil analisis yang dipergunakan untuk mengamati dan menggambarkan data yang telah dikumpulkan dengan tidak bermaksud mengambil kesimpulan secara generalisasi (Sugiyono, 2016:147). Hasil pengelolaan data sample yang digunakan dengan memakai program SPSS didapatkan infomasi statistic deskriptif yang menginformasikan tentang nilai terkecil, terbesar, rata-rata serta nilai standar deviasi pada variabel yang diuji.

Tabel 3.

Uji statistic Deskriptif

\begin{tabular}{lccccc}
\hline & N & Minimum & Maksimum & Rata-rata & Stad.Deviasi \\
\hline Rasio perputaran modal kerja & 60 & $-14,92$ & 37,32 & 4,8392 & 8,99647 \\
Rasio cepat & 60 & 0,12 & 7,36 & 1,6543 & 1,47764 \\
Rasio utang terhadap ekuitas & 60 & $-1,59$ & 3,03 & 0,8327 & 0,68469 \\
Rasio pengembalian aset & 60 & $-9,71$ & 28,33 & 7,8005 & 6,62122 \\
\multicolumn{1}{c}{ Jumlah N } & 60 & & & & \\
\hline
\end{tabular}

Sumber:diolah oleh penulis, 2020

Hasil penelitian menunjukkan jumlah data pengamatan keseluruhan sebananya 60 data dengan periode waktu selama 5 tahun (2014-2018). Data statistik deskriptif menunjukkan perolehan mean untuk varibel rasio perputaran modal kerja 4,8392 dengan standart deviasi 8,99647. Nilai terkecil (minimal) dari perputaran modal kerja -14,92 yang diperoleh oleh perusahaan PT Multi Bintang Indonesia ditahun 2017. Nilai tertinggi (maksimal) 37,32 diperoleh perusahaan PT Sekar Bumi.

Hasil penelitian pada tabel menunjukkan nilai rata-rata untuk rasio cepat sebesar 1,6543, standart deviasi 1,47764. Nilai minimum rasio cepat 0,12 diperoleh PT Indofood CBP Sukses Makmur tahun 2016, nilai maksimal 7,36 diperoleh perusahaan PT Delta Djakarta tahun 2017.

Hasil penelitian menunjukan nilai rata-rata untuk varibel rasio utang terhadap ekuitas 0,8327 dengan standart deviasi 0,68469 . Nilai minimum sebesar $-1,59$ yang diperoleh perusahaan PT tiga pilar sejahtera food tahun 2017 dan nilai maksimum 3,03 diperoleh perusahaan PT Multi Bintang Indonesia tahun 2014.

Hasil penelitian menunjukkan nilai rata-rata untuk varibel rasio pengembalian aset 7,8005 dan standart deviasi 6,62122. Nilai terendah (minimum) untuk rasio pengembalian aset sebesar -9,71 diperoleh perusahaan PT 
Tiga pilar sejahtera food tahun 2017, nilai maksimal 28,33 diperoleh perusahaan PT Delta Djakarta pada tahun 2014.

Uji normalitas ialah alat analisis yang dipergunakan untuk mengetahui data yang sedang diteliti berdistribusi normal atau tidak (Ghizali, 2018:161). Jika normal artinya data yang diuji valid. Cara mengetahui apakah data dalam penelitian berdistribusi normal atau tidak, dapat menggunakan analisis data statistic dan analisis grafik.

Tabel 4.

Uji Normalitas

\begin{tabular}{cc}
\hline & Unstandardized Residual \\
\hline $\mathrm{N}$ & 60 \\
Kolmogorov-Smimov $Z$ & 0,100 \\
Asymp.Sig (2-tailid) & 0,200 \\
\hline
\end{tabular}

Sumber: diolah oleh penulis, 2020

Hasil uji normalitas untuk penelitian ini di uji dengan cara non.parametik kolmogrof. Apabila hasil uji koefisien memperlihatkan angka lebih tinggi dari nilai signifikan pada Asymp.sig (2-tailed) yang dipergunakan pada penelitian $(0,05)$ maka hal itu menunjukkan model dalam penelitian berdistirbusi nomal. Apabila hasil koefisien pada Asymp.sig (2-tailed) menghasilkan nilai yang lebih rendah dari 0,05 maka model yang dipergunakan pada penelitian tidak normal.

Berdasarkan hasil hasil analisis yang diperoleh menggunakan uji statistic non parameteik kolmogrof-smirnov pada tabel memperlihatkan nilai asymp.sig 0,200. Nilai ini jika dibandingkan 0,05 (tarif siginifikan $5 \%$ atau $a=5 \%$ ) lebih tinggi, sehingga dapat diartikan distribusi pada penelitian dari variabel residual berdistribusi normal.

Menurut Ghozali (2018:107) multikolineatitas menunjukkan ada tidaknya hubungan antara variabel bebas. Bentuk regresi yang benar dalam suatu riset menunjukkan tidak terjadi hubungan antar variabel bebas.

Tabel 5.

Uji Multikolonieritas

\begin{tabular}{lcc}
\hline \multicolumn{1}{c}{ Model } & Tolerance & VIP \\
\hline Rasio Perputaran Modal Kerja & 0,985 & 1,016 \\
Rasio Cepat & 0,863 & 1,158 \\
Rasio Utang terhadap Ekuitas & 0,876 & 1,142 \\
Rasio Perputaran Modal Kerja & 0,985 & 1,016 \\
\hline
\end{tabular}

Sumber: diolah oleh penulis, 2020

Berdasarkan hasil analisis, nilai tolerance pada variabel independen memiliki nilai lebih tinggi dari 0,10 . Nilai VIP juga memperlihatkan ketiga variabel bebas pada penelitian tidak menunjukkan nilai lebih dari 10. Nilai VIP variabel pada independen memperlihatkan untuk variabel rasio perputaran modal kerja VIP 1,016, rasio cepat memiliki nilai VIP 1,158 dan rasio utang terhadap 
ekuitas memiliki nilai VIP 1,142 Yang berarti dalam penelitian data dari model regresi terbebas dari multikolonieritas.

Untuk mendeteksi ada tidaknya ketidaksinkronan dari beberapa residual pengamat pada model regresi dapat menggunakan analisis heterokedastisitas Ghozali (2018:98). Bentuk regresi yang benar dalam penelitian ialah tidak terjadi gejala heterokedastisitas.

Tabel 6.

Uji Heterokedastisitas

\begin{tabular}{lcc}
\hline \multicolumn{1}{c}{ Model } & $\mathbf{t}$ & sig \\
\hline Constan & 2,158 & 0,035 \\
Rasio Perputaran Modal kerja & 0,468 & 0,641 \\
Rasio Cepat & $-0,255$ & 0,800 \\
Rasio Utang terhadap Ekuitas & $-1,623$ & 0,110 \\
\hline
\end{tabular}

Sumber: diolah oleh penulis, 2020

Hasil penelitian menunjukkan nilai siginifikansi uji heterokedastisitas menggunakan uji park pada tabel 6 , dimana nilai signifikan untuk varibel rasio perputaran modal kerja, rasio cepat dan rasio utang terhadap ekuitas lebih besar dari 0,05 (tarif siginifikan 5\% atau $a=5 \%$ ) Yang artinya bahwa ketiga variabel terbebas atau tidak terjadi gejala heterokedastisitas.

Untuk mengetahui ada tidaknya hubungan antar variabel independen dan variabel dependen pada periode sekarang dengan periode sebelumnya, metode yang sering dipergunakan adalah dengan uji statistic Durbin-watson (Ghozali, 2018:107).

Tabel 7.

Uji Autokorelasi

\begin{tabular}{cccccc}
\hline Model & $\mathbf{R}$ & R.Square & Ad.R.Square & Std.Eror & Durbin-Wastson \\
\hline 1 & $0,742^{\mathrm{a}}$ & 0,551 & 0,527 & 4,55311 & 1,798 \\
\hline
\end{tabular}

Sumber: diolah oleh penulis,2020

Hasil penelitian menunjukkan nilai Durbin-Wastson pada tabel 7 dalam penelitian ini sebesar 1,798. Nilai ini memiliki batas bawah (dL) untuk variabel (K) 3 adalah 1,4797, batas atas (dU) sebesar 1,6889. Berdasarkan pengambilan keputusan, hasilnya beradaldi $\mathrm{dU}<\mathrm{d}<4$ - dU $(1,6889<1,798<2,3111)$, yang berarti bahwa penelitian tidak terjadi autokorelasi baik positif maupun negative.

Regresi linear berganda bertujuan untuk mengetahui hubungan antar variabel melalui suatu persamaan.

Berikut adalah persamaan uji regresi berganda :

$\mathrm{y}=a+\beta_{1} X_{1}+\beta_{2} X_{2}+\beta 3 X 3+e$

Dimana : 


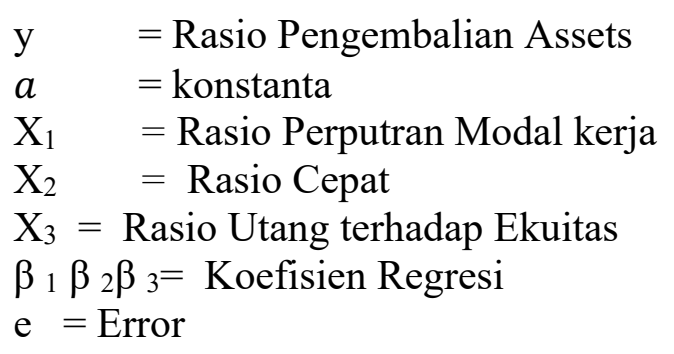

Tabel 8.

Uji Regresi Berganda

\begin{tabular}{lccccc}
\hline & Unstandartdized & Coefficents & \multicolumn{2}{c}{$\begin{array}{c}\text { Standartdized } \\
\text { Coefficients }\end{array}$} \\
\cline { 2 - 5 } \multicolumn{1}{c}{ Model } & $\mathbf{B}$ & Standart.Eror & Beta & t & Sig \\
\hline Constant & 0,286 & 1,415 & & 0,202 & 0,840 \\
Rasio Perputaran Modal Kerja & 0,138 & 0,066 & 0,187 & 2,073 & 0,043 \\
Rasio Cepat & 3,488 & 0,432 & 0,778 & 8,079 & 0,000 \\
Rasio utang terhadap Ekuitas & 1,294 & 0,925 & 0,134 & 1,399 & 0,167 \\
\hline
\end{tabular}

Sumber: diolah oleh penulis, 2020

Persamaan dari hasil pengujian, maka diperoleh:

$$
y=1,415+0,138 X_{1}+3,488 X_{2}+1,294 X_{3}
$$

Persamaan regresi berganda menjelaskan bilangan konstanta (a) yang dihasilkan sebesar 1,415 yang artinya jika variabel independen sama dengan 0 maka rasio pengembalian aset bertambah sebesar 1,415.

Nilai koefisien untuk variabel rasio perputaran modal kerja sebesar 0,138 yang artinya jika variabel rasio perputaran modal kerja meningkat satu satuan, akan menyebabkan nilai rasio pengembalian aset bertambah sebesar 0,138.

Nilai koefisien untuk variabel rasio cepat 3,488 artinya jika variabel rasio cepat meningkat satu satuan, akan menyebabkan nilai rasio pengembalian aset bertambah sebesar 3,488.

Nilai koefisien untuk variabel rasio hutang terhadap ekuitas 1,294 artinya jika variabel rasio utang terhadap ekuitas meningkat satu satuan akan menyebabkan nilai rasio pengembalian aset bertambah sebesar 1,294.

Uji Parsial dipergunakan untuk menganalisis sejauh mana pengaruh variabel independen secara individual berpengaruh terhadap variabel terikat (Ghozali, 2018:99). Hasil signifikansi varibel pada hasil penelitian akan dihubungankan dengan hipotesis yang diperoleh pada penelitian.

Hasil penelitian untuk uji parsial menunjukkan t hitung dari rasio perputaran diperoleh sebesar 2,073. Nilai signifikansi 0,043 lebih kecil dari 0,05 dengan begitu hipotesis $\left(\mathrm{H}_{1}\right)$ diterima, yang artinya terdapat pengaruh signifikan aktivitas yang diproksikan perputaran modal kerja terhadap profitabilitas yang di proksi rasio pengembalian asset. 
Tabel 9.

Uji Parsial

\begin{tabular}{lccccr}
\hline & Unstandartdized & Coefficents & \multicolumn{3}{c}{$\begin{array}{c}\text { Standartdized } \\
\text { Coefficients }\end{array}$} \\
\cline { 2 - 5 } \multicolumn{1}{c}{ Model } & $\mathbf{B}$ & Standart.Eror & Beta & t & Sig \\
\hline Constant & 0,286 & 1,415 & & 0,202 & 0,840 \\
Rasio Perputaran Modal Kerja & 0,138 & 0,066 & 0,187 & 2,073 & 0,043 \\
Rasio Cepat & 3,488 & 0,432 & 0,778 & 8,079 & 0,000 \\
Rasio utang terhadap Ekuitas & 1,294 & 0,925 & 0,134 & 1,399 & 0,167 \\
\hline
\end{tabular}

Sumber: diolah oleh penulis, 2020

Hasil penelitian untuk uji parsial menunjukkan t hitung dari rasio cepat diperoleh sebesar 8,079. Nilai signifikansi 0,000 lebih kecil dari 0,05 dengan demikian hipotesis $\left(\mathrm{H}_{2}\right)$ diterima. Yang artinya Likuiditas yang diproksi rasio cepat berpengaruh signifikan pada Profitabilitas yang diproksi rasio pengembalian aset.

Hasil penelitian untuk uji parsial (uji T) menunujukkan t hitung dari Rasio utang terhadap ekuitas sebesar 1,399 dan nilai signifikan 0,167 lebih besar dari 0,05 sehingga hipotesis $\left(\mathrm{H}_{3}\right)$ di tolak, yang artinya tidak ada pengaruh antara Solvabilitas yang diproksi rasio utang pada ekuitas terhadap Profitabilitas yang diproksi rasio pengembalian aset.

Tanda $(+)$ memperlihatkan arah yang saling berhubungan sedangkan tanda (-) menampilkan arah ikatan yang berbanding terbalik pada variabel bebas dan variabel terikat.

Uji simultan dipergunakan untuk menganalisis pengaruh antara variabel terikat dan variabel bebas secara bersamaan (Ghozali, 2018:99).

Tabel 10.

Uji Simultan

\begin{tabular}{cccccc}
\hline Model & Sum.of Square & Df & Mean suare & f & sig \\
\hline Regression & 1425,668 & 3 & 475,223 & 22,923 & $0,000^{\mathrm{b}}$ \\
Residual & 1160,927 & 56 & 20,731 & & \\
Jumlah & 2586,595 & 59 & & & \\
\hline
\end{tabular}

Sumber:diolah oleh penulis,2020

Hasil penelitian membuktikan nilai f hitung pada uji simultan 22,923. Nilai signifikan 0,000 dimana nilai ini lebih kecil dari 0,05. Yang artinya rasio perputaran modal kerja, rasio cepat dan rasio utang terhadap ekuitas secara bersamaan mempengaruhi rasio pengembalian aset.

Analisis koefisien determinasi dipergunakan untuk menghasilkan besarnya persentase pengaruh dari varibel bebas secara bersamaan terhadap variabel terikat. Berdasarkan koefisien determinasi akan terlihat seberapa besar persentasi variabel dependen dipengaruhi oleh variabel independen. 
Tabel 11.

Uji Koefisien Determinasi

\begin{tabular}{ccccc}
\hline Model & R & R.Square & Adj.R.Square & \multicolumn{1}{c}{ Std.Eror } \\
\hline 1 & 0,742 & 0,551 & 0,527 & 4,55311 \\
\hline Sumber: diolah oleh penulis, 2020 & & &
\end{tabular}

Sumber: diolah oleh penulis, 2020

Hasil penelitian yang telah dilakukan menunjukkan besarnya nilai $\mathrm{R} 0,742$. Artinya signifikansi antara variabel bebas dan terikat $74,2 \%$. Dari hasil persentasi disimpulkan hubungan antar variabel lumanyan kuat. Nilai R.Square 0,051 artinya ketiga variabel independen dalam memprediksi rasio pengembalian aset sebesar $55,1 \%$. Sisanya $44,9 \%$ variabel terikat dipengaruhi oleh variabel yang tidak digunakan dalam penelitian.

Penelitian ini membahas mengenai pengaruh aktivitas, likuiditas dan solvabilitas terhadap profitabilitas pada perusahaan makanan dan minuman yang terdaftar di BEI (2014-2018). Hasil penelitian ini membuktikan bahwa aktivitas yang diproksi rasio perputaran modal kerja mempengaruhi profitabilitas yang diproksi rasio pengembalian aset, Sehingga hipotesis pertama diterima. Rasio perputaran modal kerja menunjukkan seberapa besar kontribusi modal kerja untuk memperoleh penjualan bersih. Perputaran modal kerja yang cepat dipengaruhi oleh perubahan persediaan dan saldo kas yang signifikan, sehingga total aset lancar mampu untuk menutupi hutang lancar. Hutang yang kecil dan persediaan modal yang tinggi dapat meningkatkan penjualan dan kesempatan mendapatkan laba semakin tinggi. Berdasarkan Signaling theory penggunaan aktiva lancar secara efektif untuk menghasilkan penjualan bersihnya akan berdampak positif terhadap kinerja perusahaan.

Modal yang besar akan lebih efektif jika terlebih dahulu digunakan untuk menjalankan operasional perusahaan untuk meningkatkan penjualan bersih, sehingga tidak perlu melakukan pinjaman yang akan memperkecil kesempatan perusahaan memperoleh laba. Sesuai Pecking order theory perusahaan akan melakukan penambahan utang jika didalam perusahaanya mengalami kekurangan pendanaan. Hutang yang sedikit memberikan peluang untuk meningkatkan penjualan. Penelitian ini searah dengan penelitian yang dilakukan Utami dan Prasetiono, (2016) yang mengatakan bahwa aktivitas yang diproksi dengan rasio perputaran modal kerja berpengaruh pada profitabilitas yang diproksi rasio pengembalian aset.

Varibel kedua pada penelitian ini adalah likuiditas. Penelitian ini membuktikan bahwa likuiditas yang diproksi rasio cepat berpengaruh signifikan dengan profitabilitas yang diproksi rasio pengembalian aset, Sehingga hipotesis kedua diterima. Rasio cepat dipergunakan untuk mengukur tingkat efektivitas dalam memenuhi hutang jatuh temponya. Perusahaan yang memiliki tingkat likuiditas yang tinggi terhindar dari resiko kegagalan melunasi liabilitas jangka pendeknya dan akan berpengaruh pada profit yang akan diperoleh perusahaan. Aset lancar yang meningkat akan memperbesar kemungkinan adanya pembagian deviden dalam bentuk cash yang akan mempengaruhi pandangan investor terhadap perusahaan untuk menanamkan modalnya. Sesuai dengan Signaling theory perusahaan yang memilih melunasi utang lancarnya, maka perusahaan 
dikatakan berkinerja baik. Hal ini dipandang investor sebagai sinyal baik mengenai kinerja perusahaan karena berkaitan dengan masalah sensitif yang sering diperhatikan oleh pihak investor.

Jumlah modal yang besar akan menekan jumlah utang yang dimiliki perusahaan yang berpengaruh terhadap beban bunga yang harus dipenuhi akan semakin kecil. Hal ini akan mempengaruhi besarnya profit yang akan diperoleh perusahaan. Sesuai dengan Pecking order theory, perusahaan yang memiliki tingkat profitabilitas yang besar mengindikasikan perusahaan menggunakan proporsi hutang yang kecil untuk mendanai operasionalnya. Penelitian ini sesuai dengan yang dilakukan Yusra (2016) likuiditas yang diproksik rasio cepat mempunyai pengaruh positif pada profitabilitas yang diproksi rasio pengembalian ekuitas.

Varibel ketiga pada penelitian ini adalah solvabilitas. Penelitian ini membuktikan bahwa solvabilitas yang diproksi rasio utang terhadap ekuitas tidak mempengaruhi profitabilitas yang diproksi dengan rasio pengembalian aset, sehingga hipotesis ketiga ditolak. Solvabilitas adalah persentasi yang menunjukkan seberapa besar perusahaan dapat mendanai operasional menggunakan total hutang pada struktur modal perusahaan (Brigham dan Houston, 2013:142 ). Kebijakan pendanaan yang tercermin pada debt to equity ratio (DER) mempengaruhi pencapaian laba yang diperoleh perusahaan. Hutang yang lebih tinggi dari total modal mengakibatkan meningkatnya beban hutang yang harus dipenuhi oleh perusahaan. Kenaikan debt to equity ratio akan mengakibatkan menurunnya profitabilitas perusahaan yang dapat membuat pihak investor enggan untuk menanamkan modalnya, karena dikhawatirkan perusahaan gagal untuk membayar. Berdasarkan Signaling theory baik tidaknya sinyal yang diberikan manajer perusahaan mengenai kinerja perusahaan tergantung pada lamanya masa pembayaran hutang jatuh tempo yang dimiliki.

Hutang diperlukan khususnya dalam mengelola modal kerja untuk menyokong penggunaan aset lancar. Jumlah hutang yang lebih tinggi dari total modal akan berpengaruh pada kinerja perusahaan untuk mendapatkan tambahan pinjaman dari pihak kreditur. Rasio yang kecil mengindikasikan aset perusahaan yang didanai hutang jumlahnya sedikit. Sesuai Pecking order theory, perusahaan untuk mengambil keputusan dalam pembiayaan operasional diputuskan secara bertingkat dimulai dari pembiayaaan yang beresiko terkecil. Penelitian ini tidak sesuai dengan penelitian terdahulu yang ada dihipotesis, dimana menurut Dwiputri dkk, (2019) solvabilitas yang diproksi dengan rasio utang pada ekuitas berpengaruh signifikan terhadap profitabilitas yang diproksi rasio pengembalian aset.

\section{SIMPULAN}

Berdasarkan Penelitian yang telah dilakukan dan pembahasan yang telah dijelaskan, didapatkan kesimpulan pada penelitian yaitu aktivitas mempengaruhi profitabilitas pada perusahaan subsector makanan dan minuman yang terdaftar di BEI (2014-2018). Rasio perputaran modal kerja yang tinggi mengindikasikan 
banyak modal yang dapat direalisasikan untuk mendukung kegiatan operasional perusahaan yang berdampak pada peningkatkan profitabilitas.

Likuiditas mempengaruhi profitabilitas pada perusahaan subsector makanan dan minuman yang terdaftar di BEI (2014-2018). Aset lancar yang selalu meningkat terus menerus mengindikasikan perusahaan sanggup untuk memenuhi utang jatuh temponya. Sehingga posisi keuangan dimata kreditur juga semakin baik. Semakin tinggi aktiva lancar kesempatan memperoleh laba semakin besar. Solvabilitas tidak mempengaruhi profitabilitas pada perusahaan subsector makanan dan minuman yang terdaftar di BEI (2014-2018). Utang yang lebih besar dipergunakan untuk menjalankan aktivitas dibandingkan dengan modal milik perusahaan sendiri berdampak terhadap menurunnya profitabilitas.

Saran berdasarkan hasil penelitian yang sudah di peroleh bagi perusahaan, diharapkan untuk dapat mengoptimalkan rasio aktivitas yang diproksi dengan rasio perputaran modal kerja dan rasio likuiditas yang diproksi dengan rasio cepat karena kedua variabel ini memiliki pengaruh terhadap peningkatan profitabilitas perusahaan. Bagi peneliti selanjutnya, disarankan menggunakan variabel lain diluar penelitian ini, agar mendapatkan hasil yang lebih konsisten dan juga kepada peneliti selanjutnya untuk menambahkan periode tahun penelitian agar mendapatkan hasil penelitian yang lebih baik.

\section{REFERENSI}

Agus wibowo, S. wartin. (2013). Efisiensi Modal Kerja, Likuiditas Dan Leverage Terhadap Profitabilitas Pada Perusahaan Manufaktur Di BEI. Jurnal Dinamika Manajemen, 3(1), 49-58. https://doi.org/10.15294/jdm.v3i1.2459

Alexandre \& Wiksuana. (2018). Pengaruh Likuiditas, Solvabilitas Dan Aktivitas Terhadap Profitabilitas Pada Perusahaan Mira-Mar Block Dili Timor Leste. E-Jurnal Ekonomi Dan Bisnis Universitas, 2, 575-614.

Brigham dan Houston. (2013). Dasar Dasar Manajemen Keuangan. Salemba Empat.

Dwi, E., \& Febrianto, A. (2015). Pengaruh Rasio Likuiditas Dan Solvabilitas Terhadap Profitabilitas dengan Pendekata. 4(8), 94-101.

Dwi Putri, V. A., Nurcholisah, K., \& Nurhayati. (2019). Pengaruh Likuiditas dan Solvabilitas terhadap Profitabilitas ( Studi Empiris pada Perusahaan Sektor Pertambangan Batubara yang Terdaftar di Bursa Efek Indonesia Periode 2011-2015 ). Jurnal Prosiding Akuntansi Unisba, 5(1), 109-114.

Fadhilah, A. (2016). Pengaruh Likuiditas dan Solvabilitas Terhadap Profitabilitas perusahaan pada Sub Sektor Makanan dan Minuman yang terdaftar di Bursa Efek Indonesia periode 2013 - 2016. (June).

Ghozali, I. (2018). Aplikasi Analisis Multivariate Dengan Program IBM SPSS 25. 
Semarang: UNDIP PRESS.

Harmono. (2014). Manajemen Keuangan. Jakarta: PT Bumi Aksara.

Intan Eprilia, D. L. S. (2020). Pengaruh Rasio Likuiditas dan Rasio Aktivitas Terhadap Kinerja Kenangan Perusahaan Manufaktur di Bursa EFek Indonesia. 4(1), 160-170.

Iskandar, T., Dp, E., \& Darlis, E. (2014). Pengaruh Perputaran Modal Kerja, Struktur Modal Dan Likuiditas Terhadap Profitabilitas Perusahaan Industri \& Chemical di Bursa Efek Indonesia. Jurnal Online Mahasiswa Fakultas Ekonomi Universitas Riau, 1(2), 1-15.

Jumono, S., \& Amalia, L. (2013). Deteksi Praktis Aplikasi Pot ( Pecking Order Theory). 4(9).

Kasmir. (2010). Pengantar Manajemen Keuangan. Jakarta: Prenadamedia Group.

Kasmir. (2016). Analisis Laporan Keuangan. Jakarta: Raja Grafindo Persada.

Kholifah, U., \& Dyah A, E. (2016). Analisis Pengaruh Efisiensi Modal Kerja, Likuiditas Dan Solvabilitas Terhadap Profitabilitas Pada Perusahaan Industri Barang Konsumsi Yang Terdaftar Di Bursa Efek Indonesia (BEI) Periode 2011 -2014. Jurnal Ekonomi Manajemen (JEM17), 1(1), 77-96.

Marzuki. (2019). Pengaruh Likuiditas dan Solvabilitas terhadap Profitbilitas pada PT Industri Jamu dan Farmasi Sido Muncul TBK. Journal of Chemical Information and Modeling, 53(9), 1689-1699. https://doi.org/10.1017/CBO9781107415324.004

Mashady, D., \& Darminto Husaini dan Ahmad. (2014). Pengaruh Working Capital Turnover (WCT), Current Ratio (CR) dan Debt To Total Assets (DTA) Terhadap Return On Investment (ROI). Jurnal Administrasi Bisnis (JAB), 7(1), 1-10. Retrieved from administrasibisnis.studentjournal.ub.ac.id

Meita Sekar Sari \& Dewi Silvia. (2018). Pengaruh Rasio Likuiditas Terhadap Profitabilitas pada PT. Mustika Ratu,Tbk Dewi. 203-210.

Nugroho, S. B. (2012). Analisis Pengaruh Efisiensi Modal Kerja, Likuiditas Dan Solvabilitas Terhadap Profitabilitas Studi Kasus pada PT. Telekomunikasi Indonesia, Tbk. Jurnal Ilmu Administrasi Bisnis, 1(2), 1-11.

Putri, L. P. (2018). Pengaruh Aktivitas Terhadap Profitabilitas Perusahaan Konstruksi Dan Bangunan Di Indonesia. Seminar Nasional Royal (SENAR), l(1), 465-468. 
Riana, D., \& Ari, L. A. D. (2016). Pengaruh Rasio Keuangan dalam Memprediksi Perubahan Laba pada Industri Farmasi ( Studi Kasus pada BEI Tahun 2011 - 2014 ). Jurnal Online Insan Akuntan, 1(1), 16-42.

Riduwan, \& Akdon. (2013). Rumus Dan Data Dalam Analisis Statistika (Kelima). Bandung: Alfabeta.

Rofiah, M., Mardani, R. M., \& Wahono, B. (2017). Pengaruh Efisiensi Modal Kerja, Likuiditas dan Solvabilitas terhadap Profitabilitas pada Perusahaan Food dan Beverage yang terdaftar di Bursa Efek Indonesia (BEI). Jurnal Ilmiah Riset Manajemen, 6(1), 33-48.

Setiawanta, Y., Azizium, M., \& Dian. (2019). Apakah sinyal kinerja keuangan masih terkonfirmasi: Studi empiris lembaga keuangan di PT . BEI transparan untuk lebih bisa bersaing (Utomo \& Setiawanta , 2011). 22(2), 289-312.

Setyoningsih, Z. H. (2014). Pengaruh Leverage, Likuiditas, dan Aktivitas terhadap Profitabilitas ( Studi Empiris pada Perusahaan yang Termasuk dalam Indeks LQ45 Non Bank di Bursa Efek Indonesia) ( The Effect of Leverage, Likuidity, and Activity to Profitability (Empirical Stud.

Sri hermuningsih. (2013). Pengaruh Profitabilitas, Growth Opportunity, Sruktur Modal Terhadap Nilai Perusahaan Pada Perusahaan Publik Di Indonesia. Bulletin of Science, Technology and Society, 18(1), 38-46. https://doi.org/10.1177/027046769801800106

Sugiyono. (2016). Metode Penelitian Kuantitatif, Kualitatif, dan R\&D. Bandung: Alfabeta.

Tatang A Gumandi. (2018). Teori Sinyal Dalam Manajemen Keuangan.

Utami, R. B., \& Prasetiono. (2016). Analisis Pengaruh TATO, WCTO, dan DER terhadap Nilai Perusahaan dengan ROA sebagai variabel Intervening. Diponegoro Journal of Accounting, 5(2), 1-14.

Yudhatama, S., \& Wibowo, A. J. (2014). Penerapan Teori Pecking Order Dalam Struktur Modal (Studi Pada Perusahaan di Industri Manufaktur yang Terdaftar di Bursa Efek Indonesia Periode 205-2014. (2012), 1-15.

Yusra, I. (2016). Kemampuan Rasio Likuiditas Dan Solvabilitas Dalam Memprediksi Laba Perusahaan Perusahaan: Studi Empiris Pada Perusahaan Telekomunikasi Yang Terdaftar Di Bursa Efek Indonesia. Jurnal Benefita, 1(1), 33-42. https://doi.org/10.22216/jbe.v1i1.878 